\title{
Can climate shape flight activity patterns of Plebeia remota (Hymenoptera, Apidae)?
}

\author{
Sergio D. Hilário ${ }^{1}$, Márcia de F. Ribeiro ${ }^{2} \&$ Vera L. Imperatriz-Fonseca ${ }^{3}$
} 1. Departamento de Zoologia, Instituto de Biociências, Universidade de São Paulo, Rua do Matão, Travessa 14, nº 321, Cidade Universitária, 05508-900, São Paulo, SP, Brasil. (sedilar@usp.br,
autor para correspondência)
2. Embrapa Semi-Árido, BR 428, Km 152, Zona Rural, Caixa Postal 23, 56302-970, Petrolina, PE, Brasil. (marcia.ribeiro@cpatsa.embrapa.br)
3. Departamento de Biologia, Faculdade de Filosofia Ciências e Letras de Ribeirão Preto, Universidade de São Paulo, Av. Bandeirantes, 3900, Monte Alegre, 14040-901, Ribeirão Preto, SP,
Brasil. (vlifonse@ib.usp.br)

\begin{abstract}
RESUMO. O clima pode moldar os padrões de atividade de voo de Plebeia remota (Hymenoptera, Apidae)? A atividade do voo de forrageiras de quatro colônias de Plebeia remota (Holmberg, 1903) foi simultaneamente registrada, de dezembro de 1998 a dezembro de 1999 por meio de um sistema automatizado constituído de fotocélulas e de um Controlador Lógico Programável (CLP). As colônias eram provenientes de duas regiões diferentes: Cunha, SP e Prudentópolis, PR, Brasil. A atividade de voo de P. remota foi influenciada por fatores climáticos diferentes em cada estação. No verão, as intensidades de correlações entre a atividade de voo e os fatores climáticos foram menores do que em outras estações. Durante o outono e o inverno, a radiação solar foi o fator que mais influenciou a atividade de voo, enquanto que na primavera, esta atividade foi influenciada principalmente pela temperatura. Exceto no verão, os mesmos fatores climáticos influenciaram igualmente a atividade de voo de todas as colônias. Não foi possível distinguir diferenças nas atividades de voo segundo as origens geográficas das colônias. Informação sobre as diferenças sazonais na atividade de voo de P. remota serão úteis para a predição de cenários de distribuição geográfica perante as mudanças climáticas.
\end{abstract}

PALAVRAS-CHAVE. Abelhas sem ferrão, forrageamento, fatores climáticos, sazonalidade, distribuição geográfica.

\begin{abstract}
Flight activity of foragers of four colonies of Plebeia remota (Holmberg, 1903) was registered from December 1998 to December 1999, using an automated system (photocells and PLC system). The colonies originated from two different regions: Cunha, state of São Paulo, and Prudentópolis, state of Paraná, Brazil. Flight activity was influenced by different climatic factors in each season. In the summer, the intensity of the correlations between flight activity and climatic factors was smaller than in the other seasons. During the autumn and winter, solar radiation was the factor that most influenced flight activity, while in the spring, this activity was influenced mainly by temperature. Except in the summer, the various climatic factors similarly influenced flight activity of all of the colonies. Flight activity was not affected by geographic origin of the colonies. Information concerning seasonal differences in flight activity of $P$. remota will be useful for prediction of geographic distribution scenarios under climatic changes.
\end{abstract}

KEYWORDS. Stingless bees, foraging, climatic factors, seasonality, geographic distribution.

Currently, as climate changes have already become evident and studies on their effects focus on plant-pollinator interactions (Hegland et al., 2009), the geographic distribution of these plants/pollinators (OpdAM \& WASChER, 2004), food production, and the different future scenarios based on predicted climate changes, we find that we know very little about the effects of abiotic conditions on flight activity of native stingless bees. Relatively, little is still known how living beings adapt to temperature variation, whether through gene expression, control of growth and development, or changes in the organism as a whole (Clarke, 2003). The use of bees as ecosystem services providers has been the focus of attention for many crops (for a review, see KLEIN et al., 2007).

Study of the influence of abiotic factors on flight activity consists of the counting of bees on flowers or registration of the number of bees that leave or enter colonies, with or without visible collected material, during a certain time interval. Nogueira-Neto et al. (1959) were pioneers in this type of study in stingless bees; they recorded how climate variables affected the number of foragers on coffee flowers.

The influence of climate factors on flight activity of Meliponini bees has been the subject of some studies in recent years (Alves \& LoRENZon, 2001; Hilário \& IMPERATRIZ-FonseCA, 2002; CONTRERA et al., 2004; Borges $\&$ Blochtein, 2005; Souza et al., 2006; CARvalho-Zilse et al., 2007; CorTopassi-LaURino et al., 2007; Fidalgo \& Kleinert, 2007; Rodrigues et al., 2007; FerReIRA-Junior et al., 2010; Nates-Parra \& Rodríguez, 2011; Silva et al., 2011). All of these studies were done by visual observation, though instruments with photoelectric cells make it possible to automatically count bees (Buriolla, 1988).

Knowledge about the factors that influence stingless bee flight is very important when we consider the valuable environmental services provided by these bees. Among these services are pollination of forest trees (RouBiK, 1989), crop pollination (HeARD, 1999; Malagodi-Braga \& Kleinert, 2004; Del Sarto et al., 2005) and dispersion of seeds (BACELAR-Lima, 2006; Cortopassi-Laurino et al., 2007).

Studies of stingless bees as pollinators are just beginning (for a review, see SLAA et al., 2006). It is known that stingless bees use a higher diversity of food sources than do honey bees and have a greater diversity of foraging behaviors, pollinating both native and cultivated plants (RAMALHo et al., 1990; WiLMS \& WieCHERs, 1997; KLEINERT et al., 2009). 
As mentioned by Michener (1974), generally factors that could affect flight activity are analyzed independently, without determining if there are relations between these factors; univariate analyses are used, instead of multivariate analyses, which would be more informative. However, it is rare that rainfall distribution follows a normal distribution, which means that nonparametric analyses normally need to be implemented. Another difficulty in analysis is that flight direction and flight times have a circular distribution. This is why we previously analyzed the effects of rainfall and wind on Plebeia remota (Holmberg, 1903) flight in a totally different manner and independently (HILÁRIO et al., 2007a,b).

We analyzed the influence of climate factors and their seasonal variation on the flight activity of colonies of the stingless bee, $P$. remota, which originated from two regions with different climates, using automatic counting devices. Molecular biology data indicates that the bees of this species from these two regions constitute independent evolutionary units (FRANCISCO \& ARIAS, 2010). Thus, we also want to know if there are differences in foraging behavior of bees from these two regions.

\section{MATERIAL AND METHODS}

There are 38 species of Plebeia Schwarz, 1938, distributed from Chihuahua, Mexico, to Montevideo, Uruguay. In Brazil, P. remota is found in the states of Espírito Santo, Minas Gerais, São Paulo, Paraná, Santa Catarina and Rio Grande do Sul (Camargo \& Pedro, 2007).

Four colonies of $P$. remota, two collected from Prudentópolis, state of Paraná $\left(25^{\circ} 13^{\circ} \mathrm{S}, 50^{\circ} 59^{\prime} \mathrm{W}\right)$ and two from Cunha, state of São Paulo ( $\left.23^{\circ} 15^{\prime} \mathrm{S}, 45^{\circ} 05^{\prime} \mathrm{W}\right)$, were studied at the Bee Laboratory in São Paulo (Instituto de Biociências, Universidade de São Paulo: $23^{\circ} 33^{\prime}$ S, $\left.46^{\circ} 43^{\prime} \mathrm{W}\right)$. These colonies are henceforth designated as $\operatorname{Pr} 1, \operatorname{Pr} 2, \operatorname{Pr} 3$ and Pr4.

The flight activity of the bees that entered and left the colonies was registered with photocells installed in plastic tubes; the bees had access to the fields outside of the laboratory through these tubes. The photocells were connected to a computer through a programmable logic controller (PLC). Hourly data on flight activity (sum of entries and exits) during 281 days was registered from December 23, 1998 to December 22, 1999; this data was grouped by season of the year. Sunrise and sunset times were obtained from the Naval Observatory of the United States of America (http://aa.usno.navy.mil/). This allowed us to delimit the time intervals during which foraging by $P$. remota was possible. Flight activity during 3,829 hours (Summer, 935 h; Fall, 956 h; Winter, $1051 \mathrm{~h}$; Spring, $887 \mathrm{~h}$ ) was recorded simultaneously from the four colonies.

The climate of our study site is classified as $\mathrm{Cfb}$
(Köppen classification), being humid temperate with mild summers. The hourly air temperature, relative humidity, solar radiation, rainfall and mean wind velocity were obtained from the Laboratório de Climatologia e Biogeografia do Departamento de Geografia, FFCLH, Universidade de São Paulo. Hourly barometric pressure data was obtained from the Departamento de Ciências Atmosféricas, IAG, Universidade de São Paulo. Both weather stations were situated about $900 \mathrm{~m}$ from where the colonies were located, but in different directions.

Statistical analysis. Since analysis of the influence of climatic factors on flight activity required grouping of the data by season, we used Spearman correlations (ZAR, $1999)$ to examine the relationship between the monthly means of some of these climatic factors for 1999 and the respective historical month means from 1961-1990 (Instituto Nacional de Meteorologia). We also made a correlation analysis to measure how much each climate variable affected flight activity during the different seasons. The correlation coefficients were then ranked for each season, from the highest to the lowest value. "Top-down" correlation analysis (ZAR, 1999) was used to determine if the climate factors had different degrees of influence on flight activity within each season. We were interested in determining if the colonies that had come from Prudentópolis (Pr1 and Pr2) could be separated from those from Cunha ( $\operatorname{Pr} 3$ and $\operatorname{Pr} 4)$, presuming that their flight activity was differentially affected by abiotic factors. The same type of analysis was used to determine if the effect of the different climate factors on flight activity varied with season. A Bonferroni adjustment for the level of significance was applied to control for Type I errors when repeated tests are used (critical $p=0.0083$ ).

\section{RESULTS}

Except for relative humidity $\left(r_{s}=0.489 ; p=0.104\right)$, there were significant positive correlations between the monthly means of 1999 and the historic means for all of the climate parameters, including temperature $\left(r_{s}=\right.$ $0.951 ; p=0.001)$, barometric pressure $\left(r_{s}=0.888, p\right.$ $=0.003)$ and rainfall $\left(r_{s}=0.720 ; p=0.016\right)$. Thus, we assumed that the climatic factors analyzed in our study were similar to the ones of historic means. It means that, for instance, the summer in our study was similar to the typical summer.

Though the flight activity varied among seasons for all colonies, flight activity was positively correlated with solar radiation and negatively correlated with rainfall (Tab. I). Significant correlations were found for all colonies and during all seasons (except colony $\operatorname{Pr2,}$ during summer) between flight activity and temperature (positive) and between flight activity and relative humidity (negative, Tab. I). These correlations were highest during spring for all colonies. During winter and spring seasons, flight activity and barometric pressure were significantly and negatively correlated. During 
Tab. I. Spearman correlation coefficients $\left(\mathrm{r}_{\mathrm{s}}\right)$ between flight activity of colonies Pr1 to Pr4 of Plebeia remota (Holmberg, 1903) and climatic factors (air temperature, relative humidity, barometric pressure, solar radiation, rainfall, and wind speed), during the different seasons. Probability (p) in bold indicates a significant correlation after Bonferroni adjustment.

\begin{tabular}{|c|c|c|c|c|c|c|c|c|c|}
\hline \multirow{2}{*}{ Colony } & \multirow{2}{*}{ Climatic factors } & \multicolumn{2}{|c|}{ Summer } & \multicolumn{2}{|c|}{ Fall } & \multicolumn{2}{|c|}{ Winter } & \multicolumn{2}{|c|}{ Spring } \\
\hline & & $\mathrm{r}_{\mathrm{s}}$ & $\mathrm{p}$ & $\mathrm{r}_{\mathrm{s}}$ & $\mathrm{p}$ & $\mathrm{r}_{\mathrm{s}}$ & $\mathrm{p}$ & $\mathrm{r}_{\mathrm{s}}$ & $\mathrm{p}$ \\
\hline \multirow{6}{*}{$\operatorname{Pr} 1$} & Temperature & 0.410 & 0.0001 & 0.633 & 0.0001 & 0.509 & 0.0001 & 0.809 & 0.0001 \\
\hline & Relative humidity & -0.516 & 0.0001 & -0.589 & 0.0001 & -0.552 & 0.0001 & -0.572 & 0.0001 \\
\hline & Barometric pressure & 0.133 & 0.0001 & -0.127 & 0.0001 & -0.141 & 0.0001 & -0.427 & 0.0001 \\
\hline & Solar radiation & 0.684 & 0.0001 & 0.751 & 0.0001 & 0.727 & 0.0001 & 0.682 & 0.0001 \\
\hline & Rainfall & -0.369 & 0.0001 & -0.275 & 0.0001 & -0.131 & 0.0001 & -0.120 & 0.0004 \\
\hline & Wind speed & 0.184 & 0.0001 & 0.088 & 0.0062 & -0.050 & 0.1019 & 0.009 & 0.7753 \\
\hline \multirow{6}{*}{$\operatorname{Pr} 2$} & Temperature & -0.041 & 0.1998 & 0.421 & 0.0001 & 0.446 & 0.0001 & 0.576 & 0.0001 \\
\hline & Relative humidity & 0.006 & 0.8487 & -0.501 & 0.0001 & -0.483 & 0.0001 & -0.318 & 0.0001 \\
\hline & Barometric pressure & -0.002 & 0.9512 & -0.010 & 0.7469 & -0.137 & 0.0001 & -0.389 & 0.0001 \\
\hline & Solar radiation & 0.146 & 0.0001 & 0.688 & 0.0001 & 0.681 & 0.0001 & 0.483 & 0.0001 \\
\hline & Rainfall & -0.210 & 0.0001 & -0.275 & 0.0001 & -0.131 & 0.0001 & -0.066 & 0.0487 \\
\hline & Wind speed & 0.032 & 0.3160 & 0.115 & 0.0004 & -0.103 & 0.0008 & -0.046 & 0.1670 \\
\hline \multirow{6}{*}{$\operatorname{Pr} 3$} & Temperature & 0.399 & 0.0001 & 0.606 & 0.0001 & 0.533 & 0.0001 & 0.756 & 0.0001 \\
\hline & Relative humidity & -0.434 & 0.0001 & -0.578 & 0.0001 & -0.572 & 0.0001 & -0.506 & 0.0001 \\
\hline & Barometric pressure & 0.012 & 0.7128 & -0.097 & 0.0026 & -0.170 & 0.0001 & -0.436 & 0.0001 \\
\hline & Solar radiation & 0.559 & 0.0001 & 0.758 & 0.0001 & 0.768 & 0.0001 & 0.613 & 0.0001 \\
\hline & Rainfall & -0.324 & 0.0001 & -0.246 & 0.0001 & -0.118 & 0.0001 & -0.077 & 0.0215 \\
\hline & Wind speed & 0.197 & 0.0001 & 0.099 & 0.0021 & -0.055 & 0.0743 & 0.021 & 0.5180 \\
\hline \multirow{6}{*}{$\operatorname{Pr} 4$} & Temperature & 0.114 & 0.0005 & 0.452 & 0.0001 & 0.489 & 0.0001 & 0.688 & 0.0001 \\
\hline & Relative humidity & -0.171 & 0.0001 & -0.460 & 0.0001 & -0.500 & 0.0001 & -0.467 & 0.0001 \\
\hline & Barometric pressure & -0.016 & 0.6165 & -0.006 & 0.8417 & -0.162 & 0.0001 & -0.396 & 0.0001 \\
\hline & Solar radiation & 0.262 & 0.0001 & 0.674 & 0.0001 & 0.719 & 0.0001 & 0.607 & 0.0001 \\
\hline & Rainfall & -0.310 & 0.0001 & -0.248 & 0.0001 & -0.104 & 0.0007 & -0.104 & 0.0018 \\
\hline & Wind speed & 0.017 & 0.5934 & 0.154 & 0.0001 & -0.050 & 0.1005 & 0.001 & 0.9613 \\
\hline
\end{tabular}

Tab. II. "Top-Down" ( $\mathrm{r}_{\mathrm{T}}$ ) correlation coefficients between pairs of colonies of Plebeia remota (Holmberg, 1903), for the different seasons. Probability values $(\mathrm{p})$ in bold indicate significance after Bonferroni adjustment. Significant correlations indicate that the abiotic factors had a similar influence on the flight activity of the two colonies.

\begin{tabular}{|c|c|c|c|c|c|c|c|c|}
\hline \multirow{2}{*}{$\begin{array}{l}\text { Seasons } \\
\text { Comparisons }\end{array}$} & \multicolumn{2}{|c|}{ Summer } & \multicolumn{2}{|c|}{ Fall } & \multicolumn{2}{|c|}{ Winter } & \multicolumn{2}{|c|}{ Spring } \\
\hline & $\mathrm{r}_{\mathrm{T}}$ & $\mathrm{p}$ & $\mathrm{r}_{\mathrm{T}}$ & $\mathrm{p}$ & $\mathrm{r}_{\mathrm{T}}$ & $\mathrm{p}$ & $\mathrm{r}_{\mathrm{T}}$ & $\mathrm{p}$ \\
\hline 1 vs. 2 & 0.212 & 0.295 & 0.919 & 0.016 & 1.000 & 0.0001 & 0.969 & 0.005 \\
\hline 1 vs. 3 & 1.000 & 0.0001 & 0.989 & 0.002 & 1.000 & 0.0001 & 1.000 & 0.0001 \\
\hline 1 vs. 4 & 0.335 & 0.239 & 0.919 & 0.016 & 1.000 & 0.0001 & 1.000 & 0.0001 \\
\hline 2 vs. 3 & 0.212 & 0.295 & 0.930 & 0.012 & 1.000 & 0.0001 & 0.969 & 0.005 \\
\hline 2 vs. 4 & 0.928 & 0.014 & 1.000 & 0.0001 & 1.000 & 0.0001 & 0.969 & 0.005 \\
\hline 3 vs. 4 & 0.335 & 0.239 & 0.930 & 0.012 & 1.000 & 0.0001 & 1.000 & 0.0001 \\
\hline
\end{tabular}

fall season, significant positive correlations were found between flight activity and wind speed for all colonies (Tab. I).

The degree of correlation between climate factors and flight activity was generally weakest during summer. The climate factors that most influenced flight activity varied among colonies. Solar radiation influenced flight activity in the colonies $\operatorname{Pr} 1$ and $\operatorname{Pr} 3$ and rainfall influenced the colonies $\operatorname{Pr} 2$ and $\operatorname{Pr} 4$. During fall and winter, solar radiation was the factor that most affected flight activity for all colonies, followed by relative humidity and temperature. During spring, flight activity was mainly affected by temperature and by solar radiation, though relative humidity and barometric pressure also affected colony flight activity.

When pairs of colonies were compared during the different seasons (Tab. II), we verified that the various climate factors equally affected the flight activity of all of the P. remota colonies. However, during summer, the factors that most influenced flight activity of colonies $\operatorname{Pr} 1$ and $\operatorname{Pr} 3$ were different from those that most affected the flight activity of colonies Pr2 and Pr4.

When we compared seasons for the different colonies (Tab. III), we found that the same climate factors affected $P$. remota flight activity for all colonies in fall and winter. These same climate factors also affected the flight activity of colonies Pr1 and Pr3 during summer.

The variation in flight activity patterns of the four colonies of $P$. remota as affected by time of day, temperature, relative humidity, solar radiation and barometric pressure differed with season (Figs 1-4). During summer (Fig. 1) and spring (Fig. 4), two plateaus were often seen, with a relative decline in flight activity approximately 12:00 - 13:00 h (Fig. 1) and 11:00 h (Fig. 4), among colonies Pr2, Pr3 and Pr4. The decrease in flight activity appears to be related to 
Tab. III. Top-Down" $\left(\mathrm{r}_{\mathrm{T}}\right.$ ) correlation coefficients between pairs of seasons, for all of the colonies of Plebeia remota (Holmberg, 1903). A probability value (p) in bold indicates significance after Bonferroni adjustment. Significant values indicate that the abiotic factors had similar degrees of influence on flight activity of individual colonies during the different seasons.

\begin{tabular}{lccccccccc}
\hline Colonies & \multicolumn{2}{c}{$\operatorname{Pr} 1$} & \multicolumn{2}{c}{$\operatorname{Pr} 2$} & \multicolumn{3}{c}{$\operatorname{Pr} 3$} & \multicolumn{2}{c}{$\operatorname{Pr} 4$} \\
Comparisons & $\mathrm{r}_{\mathrm{T}}$ & $\mathrm{p}$ & $\mathrm{r}_{\mathrm{T}}$ & $\mathrm{p}$ & $\mathrm{r}_{\mathrm{T}}$ & $\mathrm{p}$ & $\mathrm{r}_{\mathrm{T}}$ & $\mathrm{p}$ \\
\hline Summer vs. fall & 0.919 & 0.016 & 0.212 & 0.295 & 0.930 & 0.012 & 0.335 & 0,239 \\
Summer vs. winter & 0.957 & $\mathbf{0 . 0 0 8}$ & 0.026 & 0.419 & 0.957 & $\mathbf{0 . 0 0 8}$ & 0.163 & 0,319 \\
Summer vs. spring & 0.464 & 0.208 & 0.051 & 0.396 & 0.464 & 0.208 & 0.118 & 0,347 \\
Fall vs. winter & 0.912 & 0.018 & 0.957 & $\mathbf{0 . 0 0 8}$ & 0.887 & 0.025 & 0.957 & $\mathbf{0 . 0 0 8}$ \\
Fall vs. spring & 0.701 & 0.086 & 0.344 & 0.236 & 0.676 & 0.100 & 0.464 & 0.208 \\
Winter vs. spring & 0.507 & 0.189 & 0.429 & 0.218 & 0.507 & 0.189 & 0.507 & 0.189 \\
\hline
\end{tabular}

an interaction between high degrees of solar radiation and high temperatures. During the other seasons (fall, Fig. 2; winter, Fig. 3), there was a plateau in flight activity in all of the colonies. Standard deviations were not included in these figures because their inclusion altered the scales, making comparisons more difficult.

Correlations between flight activity and climate factors can also be visualized in these figures. During summer (Fig. 1), the influence of climate factors on flight activity was weak, principally for colonies $\operatorname{Pr} 2$ and $\operatorname{Pr} 4$. In colony $\operatorname{Pr} 1$, the flight activity pattern was more closely
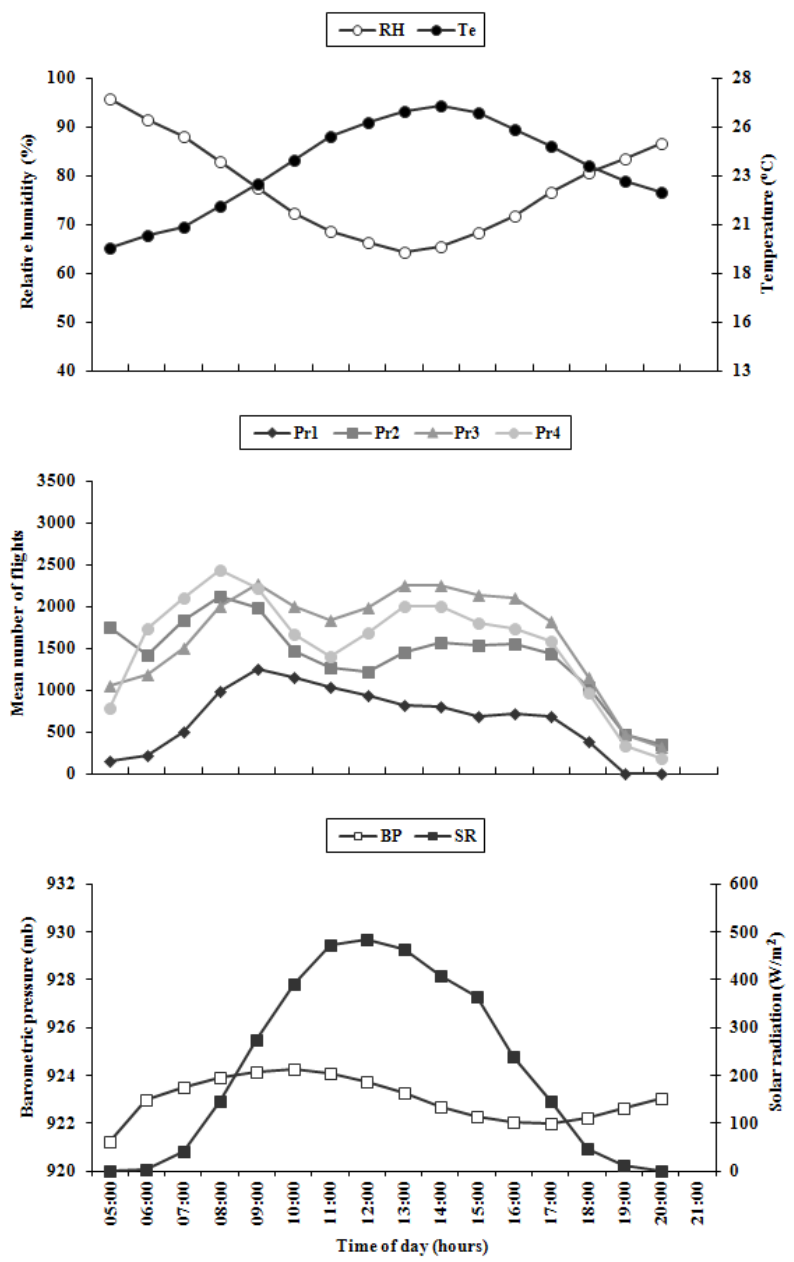

Fig. 1. Flight activity of the four colonies of Plebeia remota (Holmberg, 1903) as a function of relative humidity $(\mathrm{RH})$, temperature (Te), barometric pressure (BP) and solar radiation (SR) during the summer ( $\mathrm{n}=64$ days). related to the solar radiation and temperature cycles and was negatively correlated with relative humidity. Colony Pr3 had somewhat different flight activity patterns, though the relation with climate factors was similar to that of colony Pr1. During the other seasons, it was clear that flight activity of all of the colonies mainly accompanied solar radiation (Figs 2,3) and temperature (Fig. 4). Generally speaking (Figs 1 - 4), the greatest flight activity of $P$. remota was correlated with strong solar radiation, high temperature, low relative humidity and low barometric pressure.
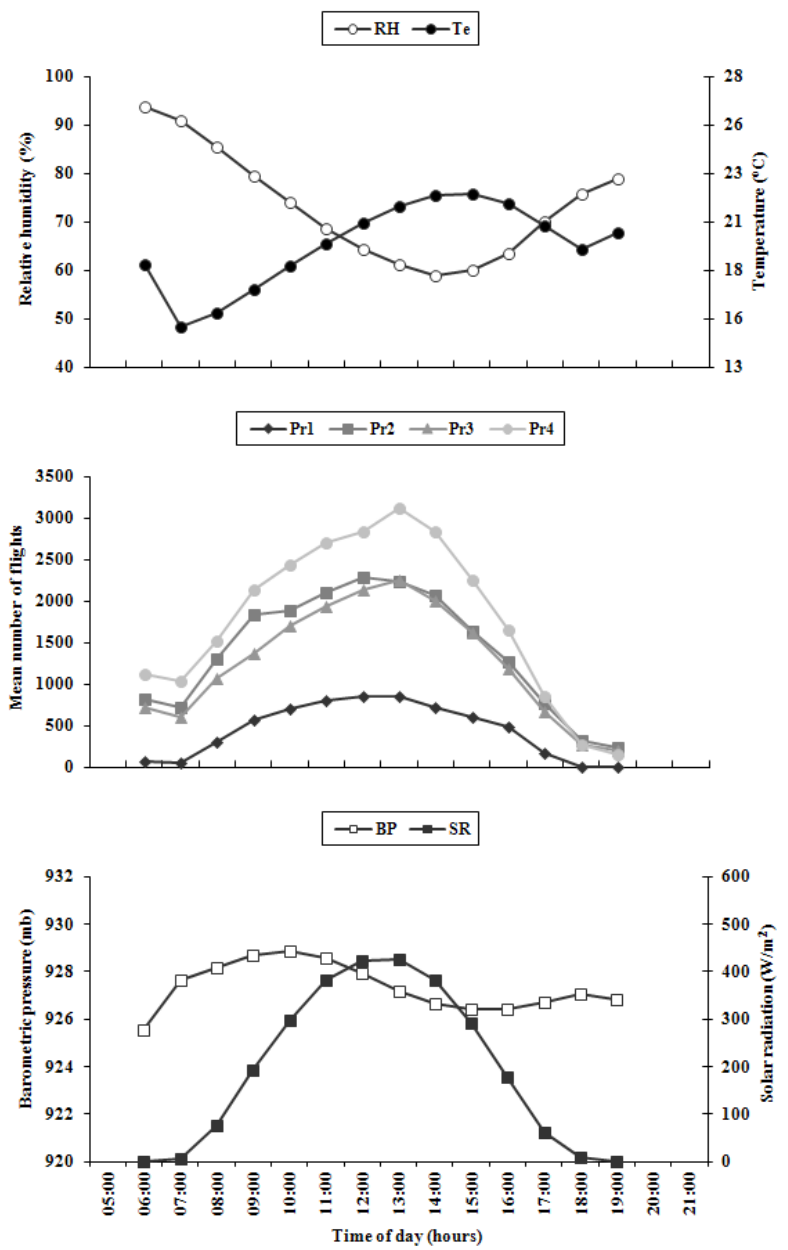

Fig. 2. Flight activity of the four colonies of Plebeia remota (Holmberg, 1903) as a function of relative humidity (RH), temperature (Te), barometric pressure (BP) and solar radiation (SR) during fall $(\mathrm{n}=76$ days). 

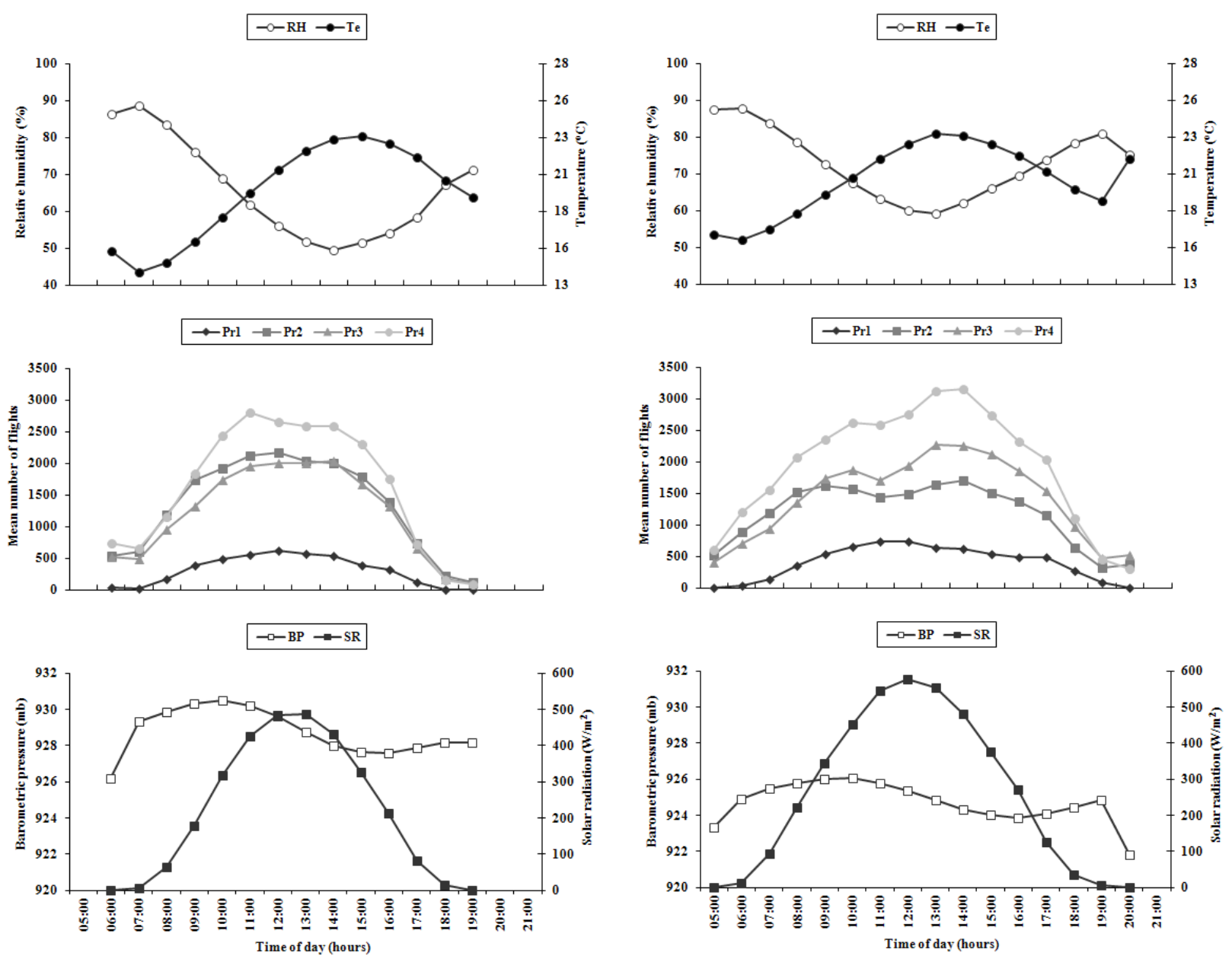

Fig. 3. Flight activity of the four colonies of Plebeia remota (Holmberg, 1903) as a function of relative humidity (RH), temperature (Te), barometric pressure (BP) and solar radiation (SR) during winter $(\mathrm{n}=$ 81 days).

\section{DISCUSSION}

The size of the bee and of the colony, the need for and the availability of floral resources and climatic factors influence the flight activity of stingless bees (Oliveira, 1973; Iwama, 1977; Kleinert-Giovannini, 1982; ImPeratriz-Fonseca et al., 1985; Hilário et al., 2000; Pick \& Blochtein, 2002a,b; Borges \& Blochtein, 2005; Souza et al., 2006). Nevertheless, some climatic factors affect flight activity more than others, as reported by Oliveira (1973) for Plebeia droryana (Friese, 1900) and Plebeia saiqui (Friese, 1900) (light intensity and temperature), by Iwama (1977), for Tetragonisca angustula (Latreille, 1811) (temperature, light intensity and relative humidity) and by HEARD \& Hendrickz (1993), for Trigona carbonaria Smith, 1854 (temperature and solar radiation).

In $P$. remota, we observed that all of the climatic factors that we analyzed influenced flight activity in some way. There was a slight tendency towards increased flight activity in all colonies with increased wind speed in the fall, while it decreased with increased rainfall during all seasons. Flight activity increased with decreasing

Fig. 4. Flight activity of the four colonies of Plebeia remota (Holmberg, 1903) as a function of relative humidity $(\mathrm{RH})$, temperature (Te), barometric pressure (BP) and solar radiation (SR) during spring ( $\mathrm{n}=$ 60 days).

barometric pressure, during winter and spring, though this tendency was stronger during spring. Barometric pressure has a direct effect on the flight dynamics of insect wings. Increased barometric pressure increases air viscosity, making flight more difficult (SPEDDING, 1992). Generally speaking, solar radiation, temperature and relative humidity, in this order, were the climate factors that most affected the flight activity of P. remota.

Kleinert-GiovanNini \& IMPERATRIZ-FonseCA (1986) noted that the effect of temperature on flight activity of Melipona marginata obscurior Moure, 1971 was maintained during two different periods. However, relative humidity had an opposite effect: between January-July 1982, flight activity was negatively correlated with relative humidity, while during October 1982-January 1983, the highest peak of flight activity occurred at higher humidities. The same tendency was found for flight activity of Plebeia sp. nov. - early referred as Plebeia pugnax Moure in litt. (HiLÁrio \& IMPERATRIZ-FonseCA, 2002). Consequently, despite the evident correlation between temperature and relative humidity (KLeINERT-GiovanNinI, 1982), we analyzed these factors separately. The greatest flight activity of 
colonies of $P$. remota was associated with periods when there was low relative humidity. Nevertheless, during summer the ideal relative humidity range for promoting flight activity was similar to that reported by IMPERATRIZFonSECA et al. (1985), in a study made in the spring and summer of $P$. remota colonies from Rio d'Oeste, state of Santa Catarina (60 - 84\%).

Temperature is one of the climate factors that most influences bee flight activity. Low temperatures limit $P$. remota flight, as can be seen in fall and winter; a reduction in temperature from 6:00 to 7:00 h, reduced flight activity. During the coldest seasons, the flight activity was more compact (concentrated in few hours) than during the other seasons. A similar pattern was found by HEARD \& HENDRICKZ (1993) for the flight activity of T. carbonaria, during a typical winter day. The ideal temperature range for flight activity of P. remota was 21 $-32^{\circ} \mathrm{C}$ during all seasons, similar to what was reported by IMPERATRIZ-FonseCA et al. (1985), who indicated 22 $29^{\circ} \mathrm{C}$. KNOLL \& IMPERATRIZ-FonseCA (1993) noted that $P$. remota foragers were not found at flowers during fall and the beginning of winter. They postulated that because of the low temperatures, there were fewer flowers and bees foraged only a few hours a day. Also, during these seasons, $P$. remota stops building brood cells, a process denominated reproductive diapause (RIBEIRo et al., 2003). Nevertheless, the flight activity of $P$. remota was not interrupted during this reproductive diapause. NunEsSiLva et al. (2010) observed that the nectar collection in $P$. remota was similar in the reproductive phase and in the reproductive diapause. On the other hand, the pollen collection in P. remota was lower in the diapause than in the reproductive phase. A similar result was found by Pick \& Blochtein (2002a) with P. saiqui.

When we analyze the raw data (not the means given in figures), we find that solar radiation above $600 \mathrm{~W} / \mathrm{m}^{2}$ decreased flight activity of $P$. remota colonies during all seasons. However, up to $600 \mathrm{~W} / \mathrm{m}^{2}$, this was the climate factor that most stimulated flight activity. This was also found for the flight activity of $T$. carbonaria during a typical summer day (HEARd \& Hendrickz, 1993). Plebeia remota foragers should avoid high solar radiation levels in order to reduce water loss. Some strategies can be used to avoid or reduce this loss; water can be taken directly from the air, when relative humidity increases (Gilles \& Delpire, 1997), or from dilute nectar collected from flowers (WILLMER et al., 2000). This extra water can be used for evaporative cooling, as a consequence of increased ventilation (PRANGE, 1996), or by exudation (RouBIK, 1989). However, evaporative cooling seems only to be possible for bee with body mass above $0.1 \mathrm{~g}$ (Prange, 1996), while P. remota foragers have a much smaller body mass, approximately $8.4 \mathrm{mg}$ (HILÁRIO \& IMPERATRIZ-FONSECA, 2002).

During summer, colonies $\operatorname{Pr} 1$ and $\operatorname{Pr} 3$ were different from colonies $\operatorname{Pr} 2$ and Pr4, in terms of the climatic factors that influence their flight activity. During the other seasons, the flight activity was influenced in a similar way by the climate factors. Consequently, based on the analysis of the effects of the climatic factors on flight activity, it was not possible to distinguish the colonies from Cunha, SP from those from Prudentópolis, PR. Kleinert-Giovannini \& Imperatriz-Fonseca (1986) found that peak flight activity of Melipona marginata marginata Lepeletier, 1836 and M. m. obscurior occurred at different temperatures, which coincided with the type of climate of the distinct regions inhabited by these subspecies. Nowadays, $M$. $\mathrm{m}$. obscurior have a new status as Melipona obscurior Moure, 1971.

How much climate factors influenced flight activity of colonies of $P$. remota varied among seasons. The seasonal cycles mold the phenology of insects through extreme temperatures, resource availability and competition, affecting population structure, mating, growth and development, among other factors (UNDERWOOD et al., 1997). Even in subtropical regions, seasonal climate changes influence the foraging behavior of bees. During the coldest periods, environmental factors probably limit the foragers physiologically, as well as reducing the availability of floral resources. During summer, these conditions are changed, and flowering is highly related to sunshine (FowLER, 1979). During part of fall and winter, the $P$. remota colonies were in reproductive diapause and flight activity was mainly influenced by solar radiation. During spring, the factor that most affected flight activity was temperature. Pick \& Blochtein (2002b) compared the flight activity of $P$. saiqui during two colony phases, during and after reproductive diapause. They indicated that solar radiation and temperature influenced flight activity during both periods, though after reproductive diapause, relative humidity also contributed.

During spring, and principally during summer, two plateaus/peaks in flight activity of $P$. remota were common. RouBiK (1989) attributed these peaks to the gathering of different resources, these being pollen in the morning and nectar in the afternoon. Similarly, the foraging pattern of Melipona scutellaris Latreille, 1811 also presented two peaks during the months of October, November and December in 2003 (PIERROT \& SchlindweIn, 2003). The flight activity plateaus found for $P$. remota could be due to a greater availability of resources at different times, in the morning and in the afternoon, independent of the resource that was collected. Pierrot \& Schlindwein (2003) found that $M$. scutellaris foragers went from nectar to pollen foraging immediately after "big bang" flowering. NAGAMITSU \& INOUE (2002) also observed a similar influence of events of this type on foraging activity of four species of Trigona Jurine, 1807.

Nevertheless, between the two plateaus found in the foraging activity of $P$. remota, flight activity decreased around 12:00 - 13:00h. This decrease could be due to a physiological limitation of $P$. remota, since 
during this interval there is an interaction between the highest intensities of solar radiation and the highest temperatures. Another possible cause is that during the hottest months, there are more bees competing for the resources, especially during this time interval. STONE et al. (1999) observed that Anthophora pauperata Walker, 1871, a desert species of solitary bee, has a bimodal foraging pattern, linked to pollen collection in the morning and in the afternoon. There is decreased activity around 12:00 $\mathrm{h}$ and the foraging peaks are separated by a two to three hour period; this decrease was not attributed to temperature, since the temperature stayed high during the intervals when foraging was at its peak.

In terms of competition for resources, in the Atlantic forest, $P$. remota has low niche overlap with Apis Linnaeus, 1758, but it competes with other stingless bee species (WILms et al., 1996). Except for Plebeia sp. nov. (Hilário et al., 2001), bees of the genus Plebeia have been described as unaggressive and they are evasive when confronted with other bee species (JoHNSON \& HuBBel, 1974). Consequently, their foragers must collect resources from plants that are not visited by other species, and thus a larger number of plant species are exploited by $P$. remota during spring, and especially during summer (Ramalho et al., 1985). Competition, the quantity and quality of resources, and especially, the need for these resources, can lead to foraging under adverse climatic conditions. In this context, during the rainy summer of 1998/1999, P. remota and Melipona bicolor bicolor Lepeletier, 1836, foragers were observed returning to their colonies with pollen in their corbiculae. The potential of $P$. remota as a pollinator of commercial crops is still unknown, though Plebeia spp. are known to intensively visit Coffea arabica L. (NogueIRA-Neto et al., 1959) and Syzygium jambos (L.) Alston (KNoll \& Imperatriz-Fonseca, 1993). Studies made of pollen grains in pollen and honey pots of $P$. remota have shown a prevalence of Arecaceae and Moraceae. Visits are also made to Anacardiaceae (KNoll \& ImPERATRIZ-FonseCA, 1993), Cunoniaceae, Lauraceae (WiLms et al., 1996), Araliaceae, Asteraceae, Burseraceae, Clethraceae, Euphorbiaceae and Myrtaceae (RAmalho, 2004).

Understanding the influence of abiotic factors on the flight activity of stingless bees is essential for developing adequate management programs for their use in the pollination of crops, both in greenhouses and in fields. Another issue involves the adaptation of bees to the changing seasons, how they tolerate some weather events and how they forage in these conditions. All this knowledge will allow us to predict the geographical distribution for host plants and stingless bees in the face of climate change.

Acknowledgements. The authors express their gratitude to Denise de Araújo Alves, Kátia Sampaio Malagodi-Braga and anonymous referees for their valuable comments and suggestions. We also extend our thanks for the financial support provided by CNPq (140169/2000-8 to SDH and 522121/97 to VLIF). This paper is dedicated to Dr. Paulo Nogueira Neto. More than a stingless bees researcher, Dr. Paulo Nogueira Neto still plays an important role in defending the Brazilian environment. Indeed, he will be remembered with affection and respect for the many generations.

\section{REFERENCES}

Alves, E. U. \& Lorenzon, M. C. A. 2001. Atividade de vôo de Melipona scutellaris (Meliponini) durante as estações seca e chuvosa na região do brejo da Paraíba. Revista Nordestina de Biologia 15(2):41-48.

Bacelar-Lima, C. G.; Freire D. C. B.; Coletto-Silva, A.; Costa, K. B.; Laray, J. P. B.; Vilas-Boas, H. C. \& Carvalho-Zilse, G. A. 2006. Melitocoria de Zygia racemosa (Ducke) Barneby \& Grimes por Melipona seminigra merrillae Cockerel, 1919 y Melipona compressipes manaosensis Schwarz, 1932 (Hymenoptera, Meliponina) em la Amazonía Central, Brasil. Acta Amazonica 36(3):343-348.

Borges, F. von B. \& Blochtein, B. 2005. Atividades externas de Melipona marginata obscurior Moure (Hymenoptera, Apidae), em distintas épocas do ano, em São Francisco de Paula, Rio Grande do Sul, Brasil. Revista Brasileira de Zoologia 22(3):680-686.

Buriolla, A. H. 1988. Uso de método eletrônico (apidômetro) na padronização do registro de atividades campeiras das abelhas, sob diferentes condições climáticas, como subsídio a genética do comportamento das abelhas africanizadas. In: SoAREs, A. E. E. \& De Jong, D. eds. Pesquisas com abelhas no Brasil. Brazilian Bee Research. Ribeirão Preto, Revista Brasileira de Genética. p.73-74.

Camargo, J. M. F. \& Pedro, S. R. M. 2007. Meliponini Lepeletier, 1836. In: Moure, J. S.; Urban, D. \& Melo, G. A. R. eds. Catalogue of bees (Hymenoptera, Apoidea) in the Neotropical region. Curitiba, Sociedade Brasileira de Entomologia. p.272-578.

Carvalho-Zilse, G.; Porto, E. L.; Silva, C. G. N. Da \& Pinto, M. de F. C. 2007. Atividades de vôo de operárias de Melipona seminigra (Hymenoptera: Apidae) em um sistema agroflorestal da Amazônia. Bioscience Journal 23(1):94-99.

Clarke, A. 2003. Costs and consequences of evolutionary temperature adaptation. Trends in Ecology and Evolution 18(11):573-581.

Contrera, F. A. L.; Imperatriz-Fonseca, V. L. \& Nieh, J. C. 2004. Temporal and climatological influences on flight activity in the stingless bee Trigona hyalinata (Apidae, Meliponini). Revista de Tecnologia e Ambiente 10(2):35-43.

Cortopassi-Laurino, M.; Velthuis, H. H. W. \& Nogueira-Neto, P. 2007. Diversity of stingless bees from the Amazon forest in Xapuri (Acre), Brazil. Proceedings of the Section Experimental and Applied Entomology of the Netherlands Entomological Society 18:105-114.

Del Sarto, M. C. L.; Peruquetti, R. C. \& Campos, L. A. O. 2005. Evaluation of the Neotropical stingless bee Melipona quadrifasciata (Hymenoptera: Apidae) as Pollinator of Greenhouse Tomatoes. Journal of Economic Entomology 98(2):260-266.

Ferreira-Junior, N. T.; Blochtein, B. \& Moraes, J. F. de. 2010. Seasonal flight and resource collection patterns of colonies of the stingless bee Melipona bicolor schencki Gribodo (Apidae, Meliponini) in na Araucaria Forest area in southern Brazil. Revista Brasileira de Entomologia 54(4):630-636.

Fidalgo, A. O. \& Kleinert, A. M. P. 2007. Foraging behavior of Melipona rufiventris Lepeletier (Apinae; Meliponini) in Ubatuba, SP, Brazil. Brazilian Journal of Biology 67(1):137-144.

Fowler, H. G. 1979. Responses by a stingless bee to a subtropical environment. Revista de Biologia Tropical 27(1):111-118.

Francisco, F. O. \& ARIAS, M. C. 2010. Inferences of evolutionary and ecological events that influenced the population structure of Plebeia remota, a stingless bee from Brazil. Apidologie 41(2):216-224.

Gilles, R. \& Delpire, E. 1997. Variations in salinity, osmolarity, and water availability: vertebrates and invertebrates. In: DANTZLER, W. H. ed. Handbook of comparative physiology. Oxford, Oxford University Press. Section 13, v. 2, p.1523-1586.

Heard, T. A. 1999. The role of stingless bees in crop pollination. Annual Review of Entomology 44:183-206.

Heard, T. A. \& Hendrickz, J. K. 1993. Factors influencing flight activity of colonies of the stingless bee Trigona carbonaria (Hymenoptera, Apidae). Australian Journal of Zoology 41(4):343-353. 
Hegland, S. J.; Nielsen, A.; Lázaro, A.; Bjerknes A.-L. \& Totland, O. 2009. How does climate warming affect plant-pollinator interactions? Ecology Letters 12(2):184-195.

HilÁrio, S. D. \& ImPERATriz-FonseCA, V. L. 2002. Seasonality influence on flight activity of Plebeia pugnax Moure (in litt.) (Hymenoptera, Apinae, Meliponini). Naturalia 27:115-123.

Hilário, S. D.; Imperatriz-Fonseca, V. L. \& Kleinert, A. M. P. 2000. Flight activity and colony strength in the stingless bee Melipona bicolor bicolor (Apidae, Meliponinae). Revista Brasileira de Biologia 60(2):299-306.

2001. Responses to climatic factors by foragers of Plebeia pugnax Moure (in litt.) (Apidae, Meliponinae). Revista Brasileira de Biologia 61(2):191-196.

Hilário, S. D.; Ribeiro, M. F. \& Imperatriz-Fonseca, V. L. 2007a. Impacto da precipitação pluviométrica sobre a atividade de vôo de Plebeia remota (Holmberg, 1903) (Apidae, Meliponini). Biota Neotropica 7(3):135-143.

2007 b. Efeito do vento sobre a atividade de vôo de Plebeia remota (Holmberg, 1903) (Apidae, Meliponini). Biota Neotropica 7(3):225-232.

Imperatriz-Fonseca, V. L.; Kleinert-Giovannini, A. \& Pires, J. T. 1985. Climate variations influence on the flight activity of Plebeia remota Holmberg (Hymenoptera, Apidae, Meliponinae). Revista Brasileira de Entomologia 29(3-4):427-434.

IwAma, S. 1977. A influência dos fatores climáticos na atividade externa de Tetragonisca angustula (Apidae, Meliponinae). Boletim de Zoologia da Universidade de São Paulo 2:189-201.

Johnson, L. K. \& HubBell, S. P. 1974. Aggression and competition among stingless bees: field studies. Ecology 55(1):120-127.

Klein, A. M.; Vaissière, B. E.; Cane, J. H.; Steffan-Dewenter, I.; Cunningham, S. A.; Kremen, C. \& Tscharntke, T. 2007. Importance of pollinators in changing landscapes for world crops. Proceedings of the Royal Society of London B 274(1608):303-313.

Kleinert, A. M. P.; Ramalho, M.; Cortopassi-Laurino, M.; Ribeiro, M. F. \& Imperatriz-Fonseca, V. L. 2009. Abelhas sociais (Bombini, Apini, Meliponini). In: PAnIzZI, A. R. \& PARrA, J. R. P. eds. Bioecologia e nutrição de insetos. Base para o manejo integrado de pragas. Brasília, Embrapa Informação Tecnológica. p. 371-424.

KiEINERT-GiovanninI, A. 1982. The influence of climatic factors on flight activity of Plebeia emerina Friese (Hymenoptera, Apidae, Meliponinae) in winter. Revista Brasileira de Entomologia 26(1):1-13.

Kleinert-Giovannini, A. \& Imperatriz-FonseCA, V. L. 1986. Flight activity and responses to climatic conditions of two subspecies of Melipona marginata Lepeletier (Apidae, Meliponinae). Journal of Apicultural Research 25(1):3-8.

Knoll, F. R. N. \& Imperatriz-FonsecA, V. L. 1993. Flores visitadas por meliponíneos (Hym., Apoidea) do gênero Plebeia. In: Nascimento-Junior, A. F. ed. Anais XI Encontro Anual de Etologia. Bauru, Universidade Estadual Paulista. p.190-202.

Malagodi-Braga, K. S. \& Kleinert, A. M. P. 2004. Could Tetragonisca angustula Latreille (Apinae, Meliponini) be effective as strawberry pollinator in greenhouses? Australian Journal of Agricultural Research 55(7):771-773.

Michener, C. D. 1974. The social behavior of the bees. Cambridge, The Belknap Press of Harvard University Press. 404p.

Nagamitsu, T. \& Inoue, T. 2002. Foraging activity and pollen diets of subterranean stingless bee colonies in response to general flowering in Sarawak, Malaysia. Apidologie 33(3):303-314.

NAtes-Parra, G. \& Rodríguez, C. A. 2011. Forrajeo en colonias de Melipona eburnea (Hymenoptera: Apidae) en el piedemonte llanero (Meta, Colombia). Revista Colombiana de Entomología 37(1):121-127.

Nogueira-Neto, P.; Carvalho, A. \& Antunes-Filho, H. 1959. Efeito da exclusão dos insetos polinizadores na produção do café Bourbon. Bragantia 18:441-468.

Nunes-Silva, P.; Hilário, S. D.; Santos-Filho, P. de S. \& ImperatrizFonseCA, V. L. 2010. Foraging activity in Plebeia remota, a stingless bee species, is influenced by the reproductive state of a colony. Psyche 2010:Article ID 241204, 16p.

Oliveira, M. A. C. 1973. Algumas observações sobre a atividade externa de Plebeia saiqui e Plebeia droryana. In: SoAres, A. E. E. \& DE Jong, D. eds. Pesquisas com abelhas no Brasil. Brazilian Bee Research. Ribeirão Preto, Revista Brasileira de Genética. p.342-343.
Opdam, P. \& WAScher, D. 2004. Climate change meets habitat fragmentation: linking landscape and biogeographical scale levels in research and conservation. Biological Conservation 117(3):285-297.

Pick, R. A. \& Blochtein, B. 2002a. Atividades de coleta e origem floral do pólen armazenado em colônias de Plebeia saiqui (Holmberg) (Hymenoptera, Apidae, Meliponini) no sul do Brasil. Revista Brasileira de Zoologia 19(1):289-300.

2002b. Atividades de vôo de Plebeia saiqui (Holmberg) (Hymenoptera, Apidae, Meliponini) durante o período de postura da rainha e em diapausa. Revista Brasileira de Zoologia 19(3):827-839.

Pierrot, L. M. \& Schlindwein, C. 2003. Variation in daily flight activity and foraging patterns in colonies of uruçu - Melipona scutellaris Latreille (Apidae, Meliponini). Revista Brasileira de Zoologia 20(4):565-571.

Prange, H. D. 1996. Evaporative cooling in insects. Journal of Insect Physiology 42(5):493-499.

Ramalho, M. 2004. Stingless bees and mass flowering trees in the canopy of Atlantic Forest: a tight relationship. Acta Botanica Brasilica 18(1):37-47

Ramalho, M.; Imperatriz-Fonseca, V. L.; Kleinert-Giovannini, A. \& Cortopassi-Laurino, M. 1985. Exploitation of floral resources by Plebeia remota Holmberg (Apidae, Meliponinae). Apidologie 16(3):307-330.

Ramalho, M.; Kleinert-Giovannini, A. \& Imperatriz-Fonseca, V. L. 1990. Important bee plants for stingless bees (Melipona and Trigonini) and Africanized honeybees (Apis mellifera) in neotropical habitats - a review. Apidologie 21(5):469-488.

Ribeiro, M. F.; Imperatriz-Fonseca, V. L. \& Santos-Filho, P. S. 2003. A interrupção da construção de células de cria e postura em Plebeia remota (Holmberg) (Hymenoptera, Apidae, Meliponini). In: Melo, G. A. R. \& Alves-dos-Santos, I. eds. Apoidea Neotropica: homenagem aos 90 anos de Jesus Santiago Moure. Criciúma, Universidade do Extremo Sul Catarinense. p.177-188.

Rodrigues, M.; Santana, W. C.; Freitas, G. S. \& Soares, A. E. E. 2007. Flight activity of Tetragona clavipes (Fabricius, 1804) (Hymenoptera: Apidae) at the São Paulo University Campus in Ribeirão Preto. Bioscience Journal 23(1):118-124.

RoubiK, D. W. 1989. Ecology and natural history of tropical bees. New York, Cambridge University Press. 514p.

Silva, M. D. e; Ramalho, M. \& Rosa, J. F. 2011. Por que Melipona scutellaris (Hymenoptera, Apidae) forrageia sob alta umidade relativa do ar? Iheringia, Série Zoologia 101(1-2):131-137.

Slaa, E. J.; Sánchez-Chaves, L. A.; Malagodi-Braga, K. S. \& Hofstede, F. E. 2006. Stingless bees in applied pollination: practice and perspectives. Apidologie 37(2):293-315.

Souza, B. A.; Carvalho, C. A. L. \& Alves, R. M. O. 2006. Flight activity of Melipona asilvai Moure (Hymenoptera: Apidae). Brazilian Journal of Biology 66(2B): 731-737.

Spedding, G. R. 1992. The aerodynamics of flight. In: Alexander, R. Mc. N. ed. Advances in comparative and environmental physiology: Mechanics of animal locomotion. New York, Springer-Verlag. v. 11, p.51-111.

Stone, G. N.; Gilbert, F.; Willmer, P. G.; Potts, S.; Semida, F. \& ZALAT, S. 1999. Windows of opportunity and the temporal structuring of foraging activity in a desert solitary bee. Ecological Entomology 24(2):208-221.

Underwood, H. A.; Wassmer, G. T. \& Page, T. L. 1997. Daily and seasonal rhythms. In: DANTZLER, W. H. ed. Handbook of comparative physiology. Oxford, Oxford University Press. Section 13 , v. 2, p. 1653-1763.

Willmer, P. G.; Stone, G. N. \& Johnston, I. A. 2000. Environmental physiology of animals. Oxford, Blackwell Science. $644 \mathrm{p}$.

WiLMS, W. \& Wiechers, B. 1997. Floral resources partitioning between native Melipona bees and the introduced Africanized honey bee in the Brazilian Atlantic rain forest. Apidologie 28(6):339-355.

Wilms, W.; Imperatriz-FonsecA, V. L. \& Engels, W. 1996. Resource partitioning between highly eusocial bees and possible impact of the introduced Africanized honeybee on native stingless bees in the Brazilian Atlantic Rainforest. Studies on Neotropical Fauna and Environment 31(3-4):137-151.

Zar, J. H. 1999. Biostatistical Analysis. Upper Saddle River, PrenticeHall. 445p.

Recebido em 25 de novembro de 2011. Aceito em 14 de setembro de 2012. ISSN 0073-4721

Artigo disponível em: www.scielo.br/isz 